\title{
Mapping oak shoot browning in SW Spain using online imagery as virtual prospecting tool
}

\author{
Luis M. Torres-Vila ${ }^{1}$ (D) A. Cristina Echave-Sanabria ${ }^{2} \cdot$ F. Javier Mendiola-Díaz ${ }^{1} \cdot$ Francisco J. Moral-García $^{3}$
}

Received: 24 October 2018 / Accepted: 7 March 2019 / Published online: 2 April 2019

(C) INRA and Springer-Verlag France SAS, part of Springer Nature 2019

\begin{abstract}
- Key message Oak shoot browning is spatially widespread throughout the region of Extremadura (SW Spain) following an aggregative distribution pattern, with a much higher prevalence in cork than in holm oak.

- Context Shoot browning is considered a potential contributing or inciting factor to oak decline in SW Iberia. Two causal agents are typically involved, Coraebus florentinus Herbst and a fungal complex in the genus Diplodia Fries (teleomorph Botryosphaeria De Cesati \& De Notaris).

- Aims Our goals were to map oak shoot browning incidence in Extremadura and to explore geographical/environmental factors potentially involved using a novel image-based prospecting method.

- Methods We used online imagery provided by Google Maps/Google Street View. A virtual sampling protocol permitted to inspect, characterise and georeference forest stands and damaged oaks throughout $>5000 \mathrm{~km}$ of navigation. Geostatistical interpolation analyses (Indicator Kriging algorithm) and validation processes were conducted to generate probability maps of shoot browning incidence.

- Results We prospected 6478 forest stands in which 3410 oaks with shoot browning symptoms were identified and georeferenced. Damage had a clustered distribution pattern both at the regional scale (IK-based probability maps) and the stand scale (fitting to negative binomial function). Factors such as oak species, stand type (pure vs. mixed), treetop orientation, tree aspect, altitude, ground slope and some interactions among them significantly affected shoot browning incidence.

- Conclusion We provide the first integrating overview on the distribution and prevalence of oak shoot browning at a regional scale in SW Spain and we also define the effects of some geographical/ecological factors involved.
\end{abstract}

Keywords Oak decline · Coraebus florentinus · Diplodia sp. · Holm oak · Cork oak · Google Maps

Handling Editor: Aurélien Sallé

Contribution of co-authors Luis M. Torres-Vila: designed the experiment, contributed to data acquisition and data analysis and wrote the first draft of the manuscript.

A. Cristina Echave-Sanabria: contributed to the experimental design and data acquisition.

F. Javier Mendiola-Díaz: contributed to data analysis and paper revision. Francisco J. Moral-García: contributed to data analysis and paper revision.

Luis M. Torres-Vila

luismiguel.torres@juntaex.es; luismiguel.torresvila@gmail.com

1 Servicio de Sanidad Vegetal, Consejería de Medio Ambiente y Rural PAyT, Junta de Extremadura, Avda. Luis Ramallo s/n, 06800 Mérida, Badajoz, Spain
2 Servicio de Producción Agraria, Consejería de Medio Ambiente y Rural PAyT, Junta de Extremadura, Avda. Luis Ramallo s/n, 06800 Mérida, Badajoz, Spain

3 Departamento de Expresión Gráfica, Escuela de Ingenierías Industriales, Universidad de Extremadura, Avda. de Elvas, s/n, 06071 Badajoz, Spain 


\section{Introduction}

Sclerophyllous oak forests are widespread across the Mediterranean Basin. In SW Iberia, two evergreen oak species are dominant, the holm oak (Quercus ilex L.) and the cork oak (Q. suber L.). Most lowland oak forests in this area have experienced a huge man-made transformation for several centuries, so their primaeval climax stage has almost completely disappeared. At present, oak forests occur as a typical open woodland similar to the savannah landscape, the so-called dehesa in Spain and montado in Portugal, which sustains a traditional agro-silvo-pastoral use shaping landscape multiplicity (Blondel 2006; Bugalho et al. 2011; Torres-Vila et al. 2017). Open oak woodlands present outstanding ecological and socioeconomic values (Montero et al. 1998; Moreno and Pulido 2009) and host the highest levels of biological diversity in Europe (Cowling et al. 1996; RamírezHernández et al. 2014; Vodka et al. 2009), so they are considered a biodiversity hotspot (Medail and Quezel 1999; Myers et al. 2000). As a result of its environmental importance, the dehesa ecosystem is protected under the EU Habitats Directive (CEC 1992).

European oaks have undergone repeated decline and mortality episodes during the past three centuries (Thomas et al. 2002), but just those that occurred since the beginning of the twentieth century are reasonably documented. The last and most severe oak decline episode was reported since the early 1980s across the Mediterranean area, and at present, it is the main phytosanitary problem affecting Iberian oak forests. The soilborne fungus Phytophthora cinnamomi Rands was first shown to be a main causal agent of oak decline (Brasier et al. 1993), but the univocal relationship between oak decline symptoms and underlying pathology still remains unclear (Brasier 1996; Desprez-Loustau et al. 2006; RodríguezMolina et al. 2005; Torres-Vila et al. 2012). Currently, it is widely accepted that oak decline, rather than a single disease, is a complex syndrome resulting from an array of interacting abiotic (drought, waterlogging and global warming) and biotic factors (bacteria, fungi and insects). Failure to find a single causal agent originated the multiple forest decline concept (including predisposing, contributing and inciting factors) integrated in the so-called decline spiral diagram (Manion 2003). Predisposing factors are inherent to environmental conditions of trees (climate and soil but also forest management strategies such as pruning and decorking) and their interaction with tree genotype. Contributing factors promote weakness and decay processes as a result of either punctual (often sudden) or recurrent biotic and abiotic impacts such as intense defoliations by insects or fungi, droughts or frosts, which rarely cause the death of trees. Inciting factors mostly include pathogens and pests that can compromise the life of the trees, among which fungi (Phytophthora de Bary, Biscogniauxia Kuntze and Diplodia Fries species) and bark- or wood- boring insects are especially noticeable (Desprez-Loustau et al. 2006; Evans et al. 2004; Sallé et al. 2014; Sturrock et al. 2011; Thomas et al. 2002; Wargo 1996).

Shoot browning symptoms originate from the drying and orange-brown-reddish colouring of oak shoots and branches in which dead leaves often remain attached for months in a characteristic marcescent state (Fig. 1), the so-called banderolas (pennons) or fogonazos (flashes) in the Spanish language. Two endemic causal agents are typically involved, the jewel beetle Coraebus florentinus Herbst $(=C$. fasciatus Villers) (Coleoptera: Buprestidae), and a fungal complex in the genus Diplodia (teleomorph Botryosphaeria De Cesati \& De Notaris), mainly $D$. corticola Phillips, Alves \& Luque (teleomorph B. corticola Phillips, Alves \& Luque) but also $D$. mutila Fries apud Montagne (teleomorph B. stevensii Shoemaker). Oak shoot browning entails photosynthetic drop, vigour loss and subsequent decay of the oak trees affected, and the causal agents involved are considered potential contributing or inciting factors to oak decline in circum-Mediterranean countries (Branco et al. 2014; Linaldeddu et al. 2014; Moricca et al. 2016; Sallé et al. 2014; Sánchez et al. 2003).

Coraebus florentinus larvae are xylophagous and mainly develop at the expense of the shoots of several Quercus species, especially $Q$. ilex and $Q$. suber. After mating in JuneJuly, C. florentinus females lay eggs in the buds and bark of young shoots (1-2 years old) usually one egg per shoot. Egg hatching occurs within 2 weeks and emerged larvae feed in the inner bark of shoots and even in developing acorns (Solinas 1974), and then they tunnel downward sinuous galleries in the sapwood, up to $1.5 \mathrm{~m}$ in length, that often cause the shoot wood to swell out. Larval development lasts 2-4 years and then the 5th-instar mature larvae, just before preparing pupation cell, excavate an annular gallery that causes girdling and subsequent death to the affected shoot by interrupting sap flow (Evans et al. 2004; Jurc et al. 2009; Sallé et al. 2014; Solinas 1971, 1974). It follows that shoot damage derives from the activity of a single larvae. Larval damage by $C$. florentinus (even if there are several damaged shoots per tree) rarely result in the death of mature oaks, as trees are able to tolerate the loss of shoots. By contrast, the beetle may be a serious threat to young oaks, particularly in plantations, since larvae, in this case, are forced to develop inside trunks (Buse et al. 2013; Evans et al. 2004).

The fungal complex D. corticola / D. mutila causes bark cankering associated with shoot and branch dieback, showing a typical wilting and browning of leaves on scattered shoots similar to beetle damage. Damaged shoots with wilted marcescent leaves attached also present girdling cankers (Muñoz López et al. 1992; Sánchez et al. 2003). Other Diplodia species also produce bark necrosis on weakened branches, but they are not able to girdle vigorous living branches (Frisullo et al. 2000; Sánchez et al. 2003). Oak shoots damaged by $C$. florentinus are usually larger (up to 
Fig. 1 A veteran cork oak in a dehesa open woodland showing multiple shoot browning symptoms in the SE aspect of the treetop. Prado de Lácara, Mérida, Spain, August 2017 (Photo L.M. Torres-Vila/SSV)

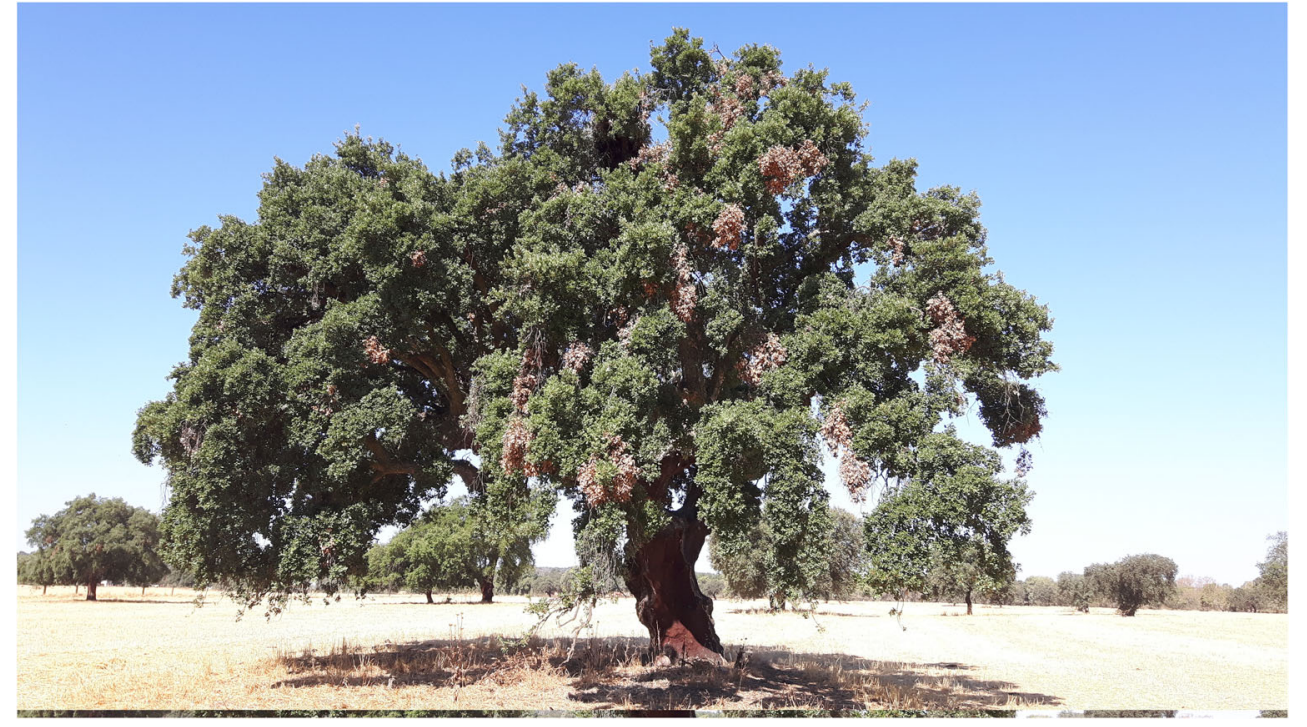

6-8 cm in diameter at the base) (Soria and Ocete 1993; Tiberi et al. 2016) than those infected by Diplodia. However, in many field situations, dried shoots look similar regardless of the causal agent involved (Muñoz López et al. 1992) as they show the same appearance and size when observed from the ground. It follows that, in spite of the distant taxonomic position of both causal agents, damage results in quite similar symptomatology, which ultimately originates from the same physiological constrain: shoot girdling and sap flow collapse. Moreover, the interspecific relationship between beetle and fungus could be more complex than expected in the studied context. Both species are frequently associated in wood samples from affected shoots, and recent research suggests that C. florentinus could play a role in the spread of Diplodia species (Panzavolta et al. 2017) with evident implications in the epidemiology of shoot browning.

Shoot browning occurrence has increased notably in recent years in SW Spain in both holm and cork oaks and there is growing evidence of its potential impact on oak decline. However, both distribution at a regional scale and ecological factors involved are poorly known. Large-scale field sampling is not cheap as it requires important material and human resources. Hence, in this study, we used a novel prospecting method based on the exploitation of the online images provided by the Google Maps/Google Street View application. This methodology has been previously used to assess the distribution in central France of the pine processionary moth, Thaumetopoea pityocampa Den. \& Schiff., based on the observation of winter larval nests (Rousselet et al. 2013). Shoot browning symptoms are conspicuous and easily discernible in evergreen oaks as they contrast strikingly with the green colour of the remainder treetop even from afar (Cárdenas and Gallardo 2013; Solinas 1974; Soria and Ocete 1993). Preliminary proofs showed that browning symptoms could be adequately identified in Google images. On the other hand, the persistence over time of damage is quite long since dried leaves do not detach and remain marcescent, adhered to the woody material for several months (Solinas 1974). Shoot browning damage produced in a given season usually persists until the appearance of new symptoms in the following season. This aspect is important because it minimises the potential bias in the observation of shoot browning derived from the date of taking the photographs provided by Google.

In the described scenario, the main goals of our study on oak shoot browning were (1) to assess the geographical distribution in the region of Extremadura, SW Spain, (2) to define risk areas using geostatistical tools, (3) to examine the effect of oak species on the prevalence, (4) to explore some geographical and environmental variables potentially involved, such as altitude, ground slope or stand aspect and (5) to provide a useful graphic output to optimise future field surveys and sampling protocols.

\section{Material and methods}

\subsection{Study site}

The study site was the entire region of Extremadura (SW Spain), which extends over $41,634 \mathrm{~km}^{2}$ and contains more than 1 million ha of oak forests, most of them open woodlands (Fig. 2a, b). Climate is typically Mediterranean with dry and warm summers (up to $40{ }^{\circ} \mathrm{C}$ ). Altitude ranges from about $150 \mathrm{~m}$ (Guadiana and Tajo river valleys) to more than $2400 \mathrm{~m}$ (mountains of the Central System in the northern region), although the oak species studied rarely populate areas above 1100-1200 m. 
Fig. 2 Spatial distribution of a holm oak (green colour) and $\mathbf{b}$ cork oak (orange colour) woodlands in the region of Extremadura (SW Spain) with indication of the stands surveyed for each oak species (black points) using online imagery provided by Google Maps and Google Street View; and probability maps of shoot browning incidence (increasing with the intensity of the red colour) for either $\mathbf{c}$ holm oak or $\mathbf{d}$ cork oak generated with the Kriging Indicator algorithm (see text)
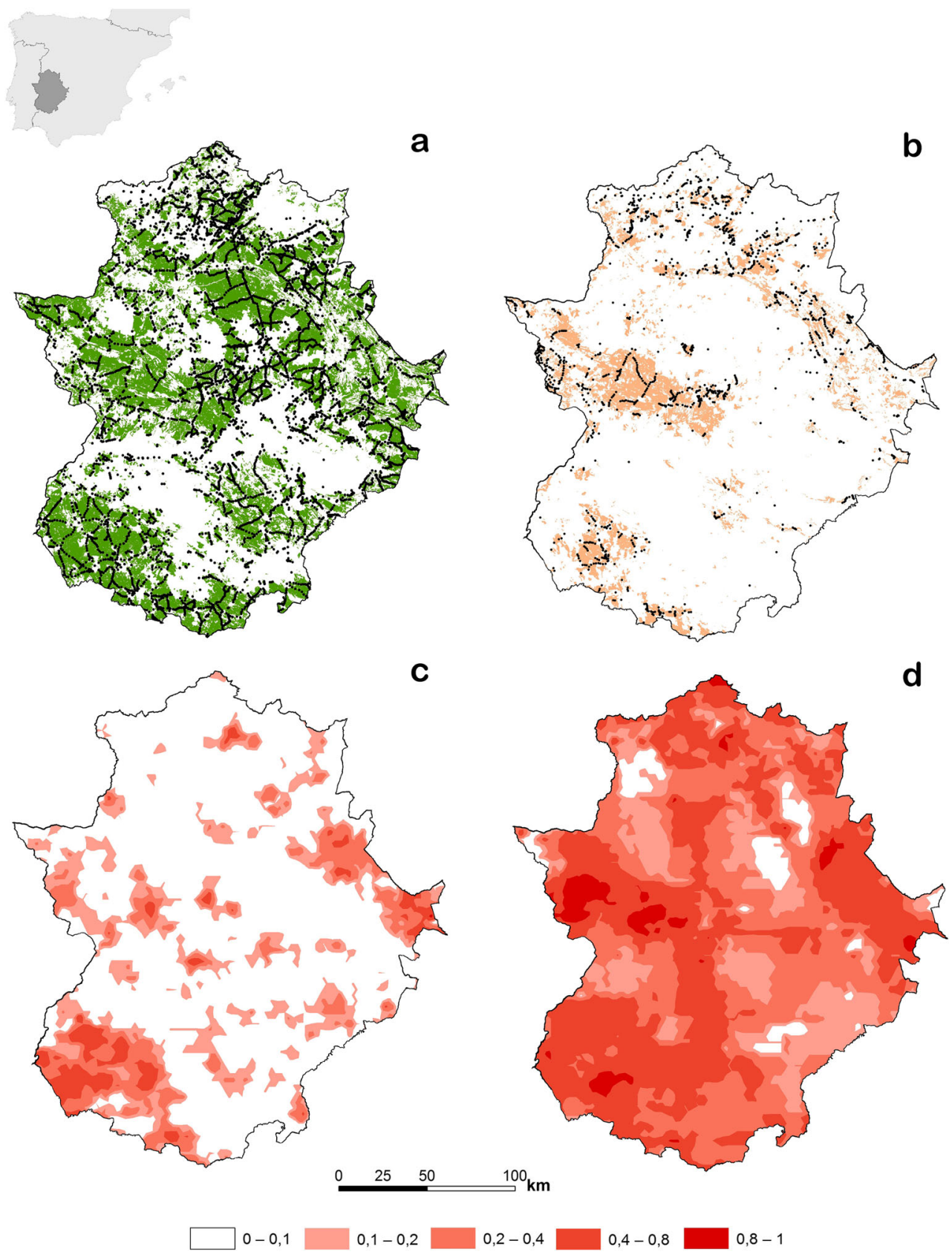

\subsection{Prospecting protocol}

As indicated in section 1, the distribution and incidence of oak shoot browning were explored by exploiting the online images provided by Google. This is a user-friendly free web mapping application that offers georeferenced satellite and terrestrial images. The feature displays high-resolution panoramas of stitched terrestrial images, which are shown as blue lines to aid navigation. Images are $360^{\circ}$ horizontal and $290^{\circ}$ vertical ground level views taken along streets, roads and forest tracks. This allows continuous navigation in which, in our study case, the driver may select single trees to be inspected
(Fig. 3a-f). In the studied region (Extremadura), imagery available covers nearly all the territory. We initially focused our study on the oak-populated areas with higher forest/ environmental significance, but we finally inspected all routes with available images (more than $5000 \mathrm{~km}$ ) looking for a better regional perspective on oak shoot browning incidence. Google Street View images were inspected online during January-May 2018.

Prospecting protocol was as follows. We first define the sampling unit (forest stand) as a transect of about $100 \mathrm{~m}$ along the route, $50 \mathrm{~m}$ forwards and backwards from the georeferenced point defining the stand position (Fig. 3g). We 
Fig. 3 Shoot browning

symptoms in a-c cork oak and d-

f holm oak as observed in

screenshots from Google Street

View (Google Maps Inc., 2018),

and $\mathbf{g}$ schematic representation of

a mixed stand ( ${ }^{\circ}$ 9957) depicting

the 100-m long transect along the

route (L, continuous red line), the

georeferenced point defining the

stand position (red triangle), the

ill-defined strip of unknown

width surrounding the transect

(dashed line) delimited by the

visual distance $(\mathrm{V})$, the damaged

trees recorded either cork oaks

(white circles) or holm oaks

(grey circles) and the damage

orientation around the treetop for

each tree (white arrows) (Google

Maps Inc. and DigitalGlobe,

2018). See text for a full

description of the prospected

stands
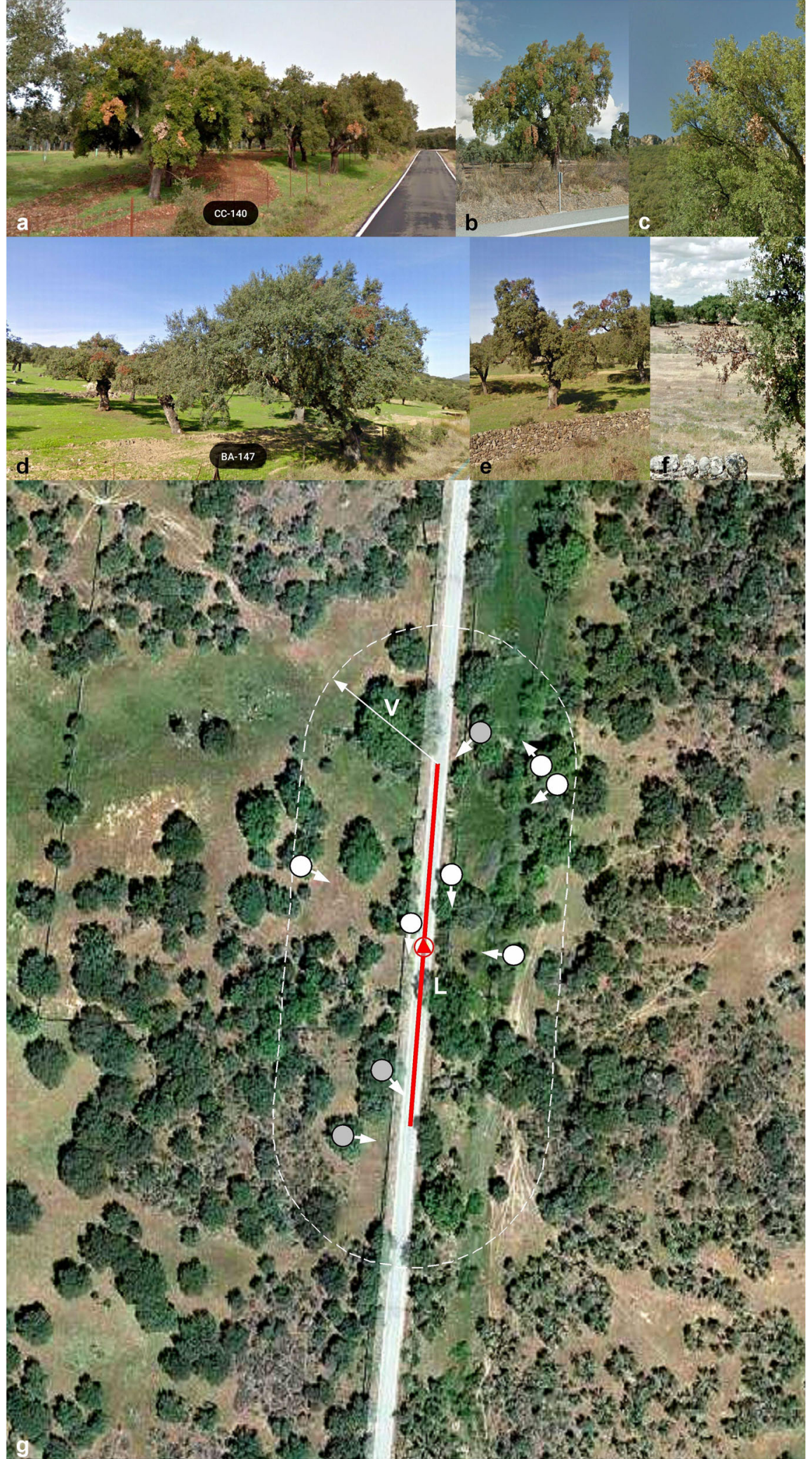

then navigated along the transect, inspecting carefully all visible treetops on both sides of the route. In practice, all the $360^{\circ}$ views required within the transect were accomplished to properly characterise every stand. When necessary, the current observation position was modified little forwards or backwards to optimise the sight line between trees. This typically 
occurred in dense stands, in those with developed understory, with tree alignments in the road margins or with very steep slopes. The stand thus defined has a track line of known length ( $L=100 \mathrm{~m}$ ) but the visual distance of the observer $(V)$ cannot be exactly determined because it depends on several factors affecting image quality including date, hour, sun elevation, shadows, cloudiness, ground slope or undergrowth, in addition to the characteristics of the stand/trees themselves (age, leafiness, density or recent pruning) and the size of browning patches (from about $30 \mathrm{~cm}$ to more than $1 \mathrm{~m}$ in diameter). The theoretical stand surface $(S)$ is calculated as $S=2 V L+\pi V^{2}$, with $L$ being the transect longitude and $V$ the visual distance, i.e., an ill-defined strip of unknown width surrounding the transect (Fig. 3g). Assuming an average value of $V=40$ $50 \mathrm{~m}, S$ would be around 1.5 ha. Note, however, that images of many stands allowed to reach $V$ values of more than $100 \mathrm{~m}$.

When a tree with shoot browning symptoms was detected (Fig. 3a-f) its position was marked in the satellite image with a pin stored in the appropriate datapoint layer (Fig. 3g, see below). The comparison of the terrestrial and aerial images at the same time allowed to position with precision the damaged trees. For this purpose, in addition to the particular arrangement of trees in a given stand, some terrain elements were helpful, such as road crossings, small constructions, stone walls or stream riverbeds. When a damaged tree was marked, the orientation of the damaged shoot around the treetop perimeter was indicated with another pin, for which it was very helpful the relative road orientation (Fig. $3 \mathrm{~g}$ ). All shoots with browning symptoms were considered regardless of the season in which they were produced. The number of damaged shoots per tree was not considered. In trees with multiple damaged shoots, damage position was marked in the treetop orientation with more damage intensity. Finally, the oak species populating the stand (irrespective of the damage status of inspected trees) were noted, labelling the stand as pure holm oak, pure cork oak or mixed stand (both cork and holm oaks). The inter-stand distance averaged about $1 \mathrm{~km}$, but it ranged between $0.25-0.5 \mathrm{~km}$ (areas with dense woodlands) and 2$3 \mathrm{~km}$ in areas with fragmented oak patches or with predominant non-target tree species. Special care was taken that the same damaged tree did not belong to two adjacent stands. During the navigation process, all georeferenced datapoints (pins) were stored orderly in homogeneous layers (WGS84 coordinate system). We compiled five main layers namely "holm oak stands," "cork oak stands," "mixed stands," "damaged holm oaks," and "damaged cork oaks." Two additional layers were also compiled, "damage orientation" with the damage position in the treetop (for each oak species), and the layer "no stand data." The datapoints in the last layer arise from sampling in deforested areas or areas populated with trees of other species (mainly deciduous oaks). These points were not used in statistical analyses but were exploited as positioning reference as they greatly facilitated navigation.
Lastly, all the information compiled in the layers was downloaded and stored in a database for further statistical and geostatistical analysis.

\subsection{Data analyses}

A geostatistical approach with ArcGIS software (version 10.3, ESRI Inc., Redlands, CA, USA) was used to model the spatial incidence of oak shoot browning at the regional level and to detect those areas with higher damage risk. The "number of visible damaged trees per stand" (per oak species) was the variable used. A more powerful variable to characterise damage (e.g., percentage of damaged trees or number of damaged trees per area unit) could not be ascertained (see above), as our image-based sampling method does not allow a simple calculation of the stand surface.

Interpolation analyses were conducted with the nonparametric IK (Indicator Kriging) algorithm using the Geostatistical Analyst extension in ArcGIS. The IK approach makes no assumption of normality and is an effective way of limiting the effect of extreme values, which was appropriate for our dataset in which there was an excess of zeros (oak stands without shoot browning symptoms). We computed IK in the same fashion as ordinary kriging to determine model values from the correlation between datapoints. The essence of the IK approach is the binomial coding of data into either 1 or 0 , depending upon its relationship to a cut-off value (Journel 1983). IK involves modelling of an indicator variogram at a range of the cut-off which has to cover the range of the input data. IK builds a cumulative distribution function at each estimate location based on the behaviour and correlation structure of the transformed datapoints in the chosen neighbourhood. Probability maps may be produced since predictions from IK are interpreted as probabilities of the variable being in the class indicated by 1 .

A validation process was performed before producing probability maps to have an idea about the reliability of the final surfaces. For this, a random subset of the original dataset (10\% of the whole data) was reserved for validation and the rest used as training dataset to develop the IK experimental variogram. Prediction error statistics were computed and used as a diagnostic tool that indicates whether kriged surfaces were reasonable (Webster and Oliver 2007). We finally generate two probability maps (for either holm or cork oak) showing the shoot browning incidence in Extremadura using the ArcGIS/ArcMap module. Mixed stands were included in these two maps but considering only the damaged trees of the oak species considered in each map. The geographic coordinate system for data analysis was ETRS89 projected in the UTM zone $30 \mathrm{~N}$.

The distribution of shoot browning damage around the treetop (eight spatial orientations were considered: N, NE, E, SE, S, SW, W and NW) was analysed by comparing observed 
and random distributions. We also explore the effects of altitude, ground slope and stand aspect on shoot browning. These explanatory variables were obtained from geographical coordinates for each stand or tree using the MDT05-LIDAR Digital Elevation Model (CNIG-IGN 2016). Variables scored in classes prior to analyses were as follows: altitude (four classes of either $<400,400-600,600-800$ or $>800 \mathrm{~m}$ above sea level), stand aspect (eight classes corresponding to the eight spatial orientations as above) and ground slope (two classes with slopes either under or above 20\%). The nonparametric Kruskal-Wallis test (Mann-Whitney $U$ test for two samples) was computed for comparison of means using SYSTAT software. The goodness-of-fit $G$ test was used to compare observed and random-expected frequency distributions (Scherrer 1984; Sokal and Rohlf 1995).

Finally, we explored shoot browning distribution at the stand scale (either in holm or cork oak) by adjusting data (number of visible damaged trees per stand) to the Poisson and Binomial Negative functions using PADIS software (moments method was implemented to estimate parameters). The fitting to the Poisson function would show a random spatial pattern while fitting to the Negative Binomial distribution would show an aggregative one.

\section{Results}

We prospected and characterised a total of 6478 forest stands (5043 holm oak stands, 682 cork oak stands and 753 mixed stands) throughout the region, in which 3410 oaks with shoot browning symptoms were identified and georeferenced (Table 1, Fig. 2a, b). Oak shoot browning was distributed along a wide altitudinal range, $158-1055 \mathrm{~m}$ in holm oak and $165-939 \mathrm{~m}$ in cork oak. Shoot browning incidence (number of visible damaged trees per stand) ranged widely between 0 and 16 (holm oak) and 0-30 (cork oak).

Geostatistical analyses showed that shoot browning distribution could be regionalised using the IK algorithm. Prediction error statistics were as follows. For holm oak, root

Table 1 Number of oak stands sampled (per cover type) and oak trees (per species within stand types) exhibiting shoot browning symptoms in the study site (Extremadura, SW Spain). Data were acquired using the mean square error was 0.27 , mean standard error 0.26 and mean standardised error 0.03 . For cork oak, root mean square error was 0.45 , mean standard error 0.45 and mean standardised error -0.02 . Consequently, in both oak species, all error values were close to zero, and moreover, root mean square error and mean standard error were very close so that probability maps generated were appropriate. Furthermore, standard deviations of the measured values in the test samples were higher than root mean square errors, which denote an effective prediction throughout the region.

Probability maps show the areas with higher prevalence for each oak species (Fig. 2c, d). Maps clearly indicate that shoot browning was more prevalent in cork than in holm oak at the regional scale. Similar results were obtained at the stand scale, damage being significantly higher in cork than in holm oak (Mann-Whitney $U$ test, $U_{1}=5,848,310, P<0.001$ ). We also detected an interaction between stand type (pure vs. mixed stand) and oak species (holm vs. cork oak) on the incidence of shoot browning. Thus, while in cork oak damage was significantly higher in pure than in mixed stands $\left(U_{1}=298,966\right.$, $P<0.001$ ), in holm oak the opposite situation occurred, damage being slightly (but significantly) higher in mixed than in pure stands $\left(U_{1}=1,679,000, P<0.001\right)$ (Fig. 4).

Shoot browning occurred in all eight spatial orientations around the treetops but frequency distribution did not follow a random pattern (Fig. 5). Damaged shoots oriented towards S-SE aspects were significantly more frequent than expected from the equiprobable theoretical distribution, both in holm oak (Goodness-of-fit test, $G_{7}=378.26, P<0.001$ ) and in cork oak $\left(G_{7}=435.82, P<0.001\right)$.

Altitude showed a host tree-dependent effect on shoot browning. So, altitude did not affect damage in cork oak (Kruskal-Wallis test, $U_{3}=6.35, P=0.10$ ), but in holm oak mean damage was significantly greater in trees living above $600 \mathrm{~m}\left(U_{3}=34.84, P<0.001\right)$ (Fig. 6).

The effect of tree aspect was different depending on oak species (in strictly statistical terms), but the trend displayed was similar. In holm oak, frequency distribution did not follow a random pattern $\left(\mathrm{G}_{7}=19.68, P<0.01\right)$ with frequencies in

online imagery provided by Google Maps/Google Street View during January-May 2018 (see text)

\begin{tabular}{|c|c|c|c|c|c|}
\hline \multirow[t]{2}{*}{ Stands/Trees } & \multicolumn{2}{|l|}{ Pure stands } & \multicolumn{2}{|c|}{ Mixed stands } & \multirow[t]{2}{*}{ Total } \\
\hline & Holm oak & Cork oak & Holm oak & Cork oak & \\
\hline Prospected stands $(n)$ & 5043 & 682 & 753 & & 6478 \\
\hline Damaged stands $(n)$ & 399 & 381 & 146 & 317 & 1243 \\
\hline Damaged stands (\%) & 7.91 & 55.87 & 19.39 & 42.10 & 19.19 \\
\hline Damaged trees $(n)$ & 751 & 1481 & 267 & 911 & 3410 \\
\hline Damaged trees per stand & $0.15 \pm 0.03$ & $2.17 \pm 0.10$ & $0.35 \pm 0.06$ & $1.21 \pm 0.07$ & $0.53 \pm 0.03$ \\
\hline
\end{tabular}

$n$, number; mean \pm standard deviation is given for the last variable 


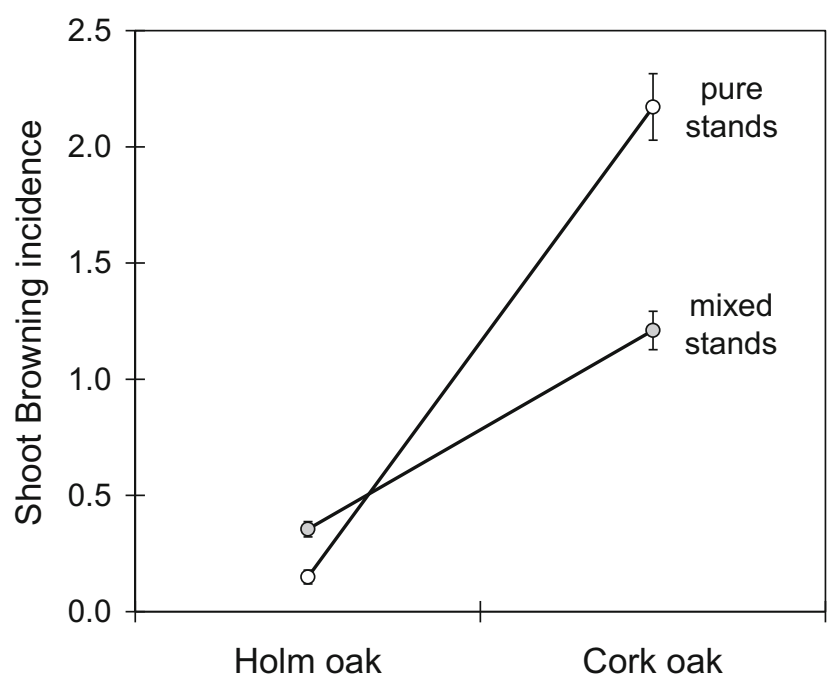

Fig. 4 Shoot browning incidence (number of visible damaged trees per stand) depending on oak species (holm oak vs. cork oak) and stand type (pure vs. mixed stands). Vertical lines are the standard error of the means. See text for a detailed statistical analysis

some warmer aspects (SW-S) higher than expected (Fig. 7). In cork oak, frequency distribution fitted to a random distribution, but this was at the limit of significance $\left(G_{7}=13.50, P=\right.$ 0.06). So, trend was comparable to that observed in holm oak, with a damage frequency somewhat higher in the SW aspect (Fig. 7).

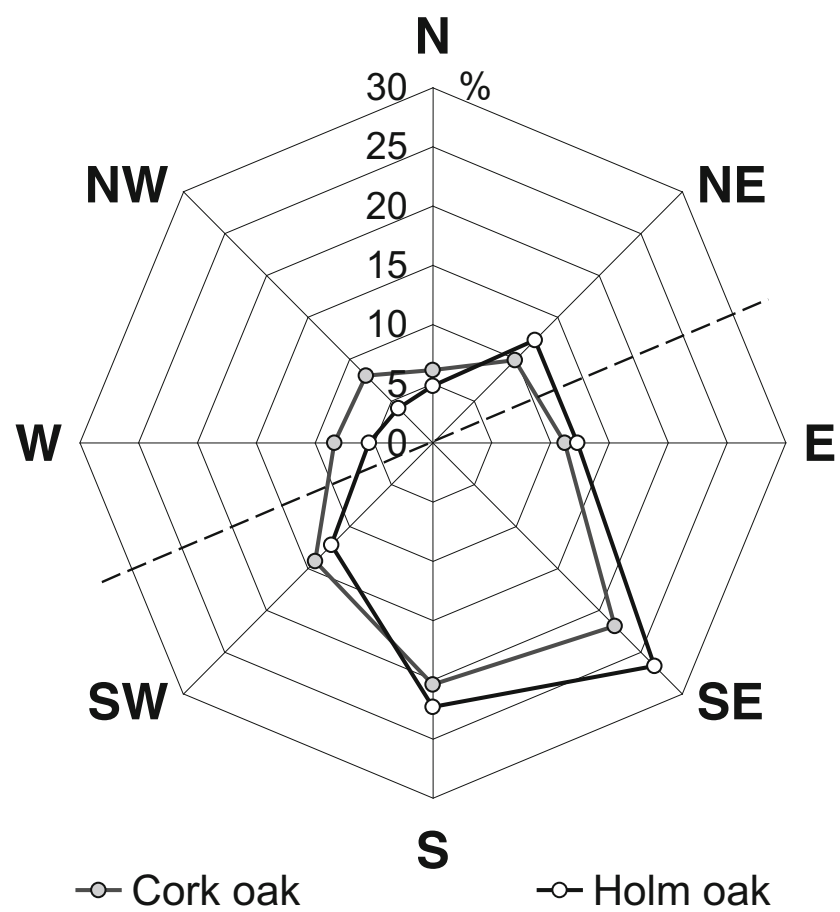

Fig. 5 Frequency distribution of shoot browning in the treetops depending on spatial orientation in cork oak and holm oak. Dashed line separates warm and cold aspects. Damage oriented towards warmer aspects (mainly SE-S) was significantly more frequent than expected from a random distribution in both oak species. See text for statistical analysis
The effect of ground slope on shoot browning showed interesting results when controlling for oak species and stand aspect (stand aspects pooled in two groups, either warm: E, SE, S, SW; or cold: NE, N, NW, W). In holm oak, there was no slope effect in both warm (Mann-Whitney $U$ test, $U_{1}=$ $286,471, P=0.27)$ and cold aspects $\left(U_{1}=237,962, P=0.26\right)$ (Fig. 8). In cork oak, browning incidence was significantly higher in high-slope warm aspects than in low-slope warm aspects $\left(U_{1}=28,989, P<0.05\right)$, while in cold aspects, an opposite tendency occurred, although at the limit of significance $\left(U_{1}=22,237, P=0.07\right)$ (Fig. 8). These results indicate a noticeable effect of the slope $\mathrm{x}$ aspect interaction regulating shoot browning incidence in cork oak.

The distribution of the variable studied (number of visible damaged trees per stand) did not fit the Poisson function either in cork oak in pure stands $\left(\chi_{5}^{2}=1050.35, n=682, P<0.001\right)$, cork oak in mixed stands $\left(\chi_{4}^{2}=790.51, n=753, P<0.001\right)$, holm oak in pure stands $\left(\chi_{1}^{2}=438.72, n=5043, P<0.001\right)$ or holm oak in mixed stands $\left(\chi_{1}^{2}=92.24, n=753, P<0.001\right)$, showing that there was a no-random pattern in the damage distribution at the stand scale. Distinctly, data fitted the Binomial Negative function in three of four cases, and even in all four cases if a more conservative probability level $(P<0.01)$ was selected: cork oak in pure stands $\left(\chi_{10}^{2}=9.85\right.$, $n=682, P=0.45)$, cork oak in mixed stands $\left(\chi_{8}^{2}=7.41, n=\right.$ 753, $P=0.49)$, holm oak in pure stands $\left(\chi_{5}^{2}=13.46, n=\right.$

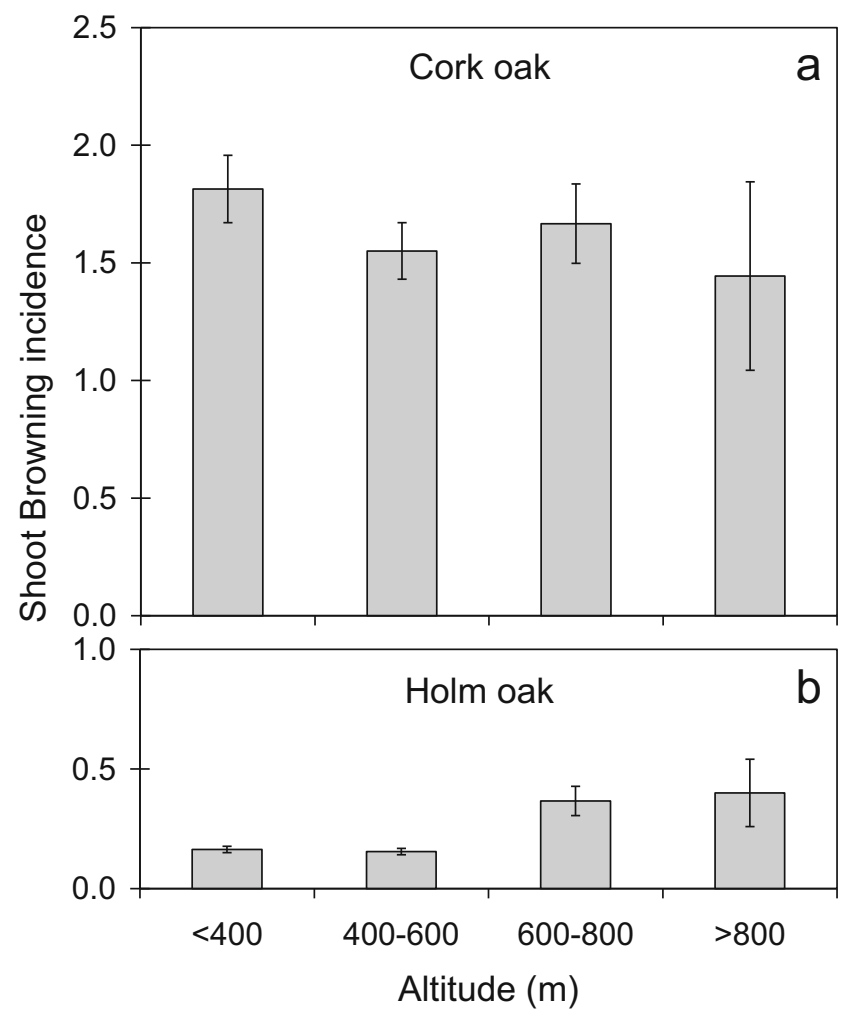

Fig. 6 Shoot browning incidence (mean number of visible damaged trees per stand) depending on altitude in a cork oak and $\mathbf{b}$ holm oak. Vertical lines are the standard error of the means. See text for statistical analysis 


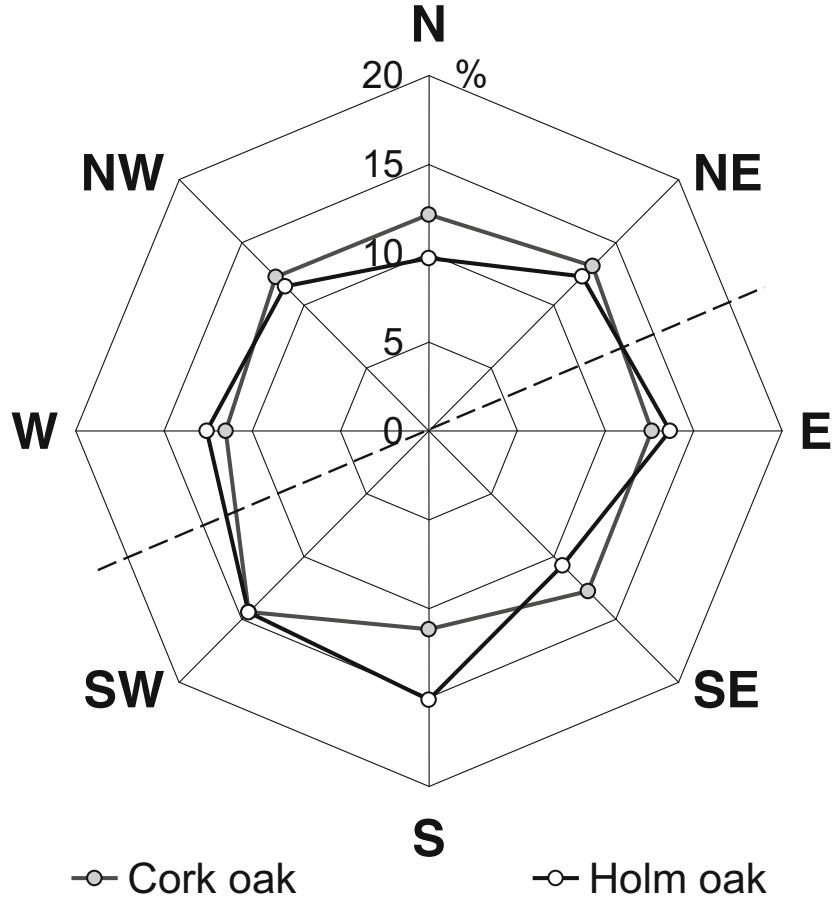

Fig. 7 Frequency distribution of shoot browning depending on tree aspect in cork oak and holm oak. Dashed line separates warm and cold aspects. See text for statistical analysis

5043, $P<0.05)$ and holm oak in mixed stands $\left(\chi_{3}^{2}=1.99\right.$, $n=753, P=0.57)$. These results overall indicate that shoot browning exhibits a clustered spatial distribution irrespective of oak species and stand type.

\section{Discussion}

The novel imagery-based prospecting methodology used in this study produced undoubted practical advantages applied to phytosanitary prospecting. Field sampling is not cheap and requires important material and human resources. Our approach greatly reduced prospecting costs, either direct (classic field surveys) or indirect (e.g., image acquisition with drones), and even avoided gas emission by vehicles. Furthermore, if Google database is regularly updated and old images remain available online, this will allow researchers to perform retrospective analyses (Rousselet et al. 2013), an especially interesting aspect in the current climate change scenario. Method also has, of course, a number of constraints. The target species must produce symptoms large enough, conspicuous, distinctive and lasting over time so that they can be unequivocally identified in the Google images. This in practice mostly restricts its use to woody host plants and drastically reduces the number of species/symptoms with phytosanitary interest that can be surveyed. An additional problem is the date of taking the images, which must coincide with the seasonal period in which symptoms are visible in the field. In addition, the date

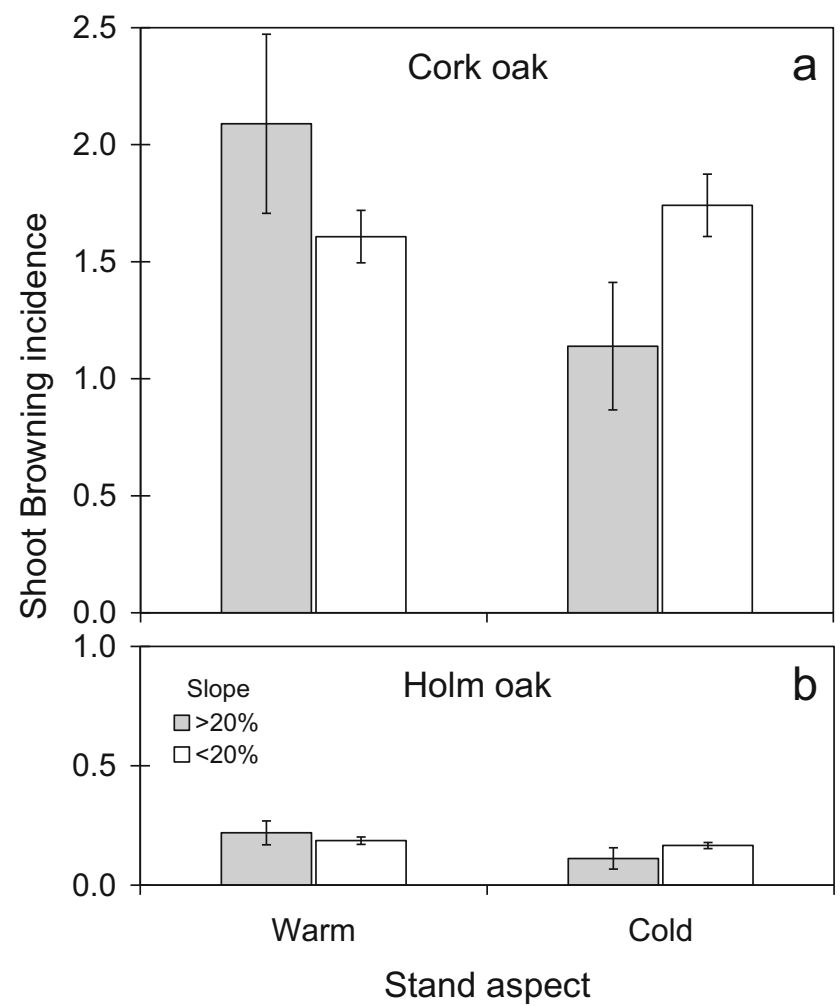

Fig. 8 Shoot browning incidence (mean number of visible damaged trees per stand) depending on stand aspect (warm vs. cold) and ground slope (under or above 20\%) in either a cork oak and b holm oak. Vertical lines are the standard error of the means. See text for a detailed statistical analysis

of images may vary throughout the studied area, increasing sampling noise. In our study case, such constraints were not problematic since oak shoot browning symptoms are large and well defined, present a characteristic brown colour that stand out in the green treetop and lasts for several months so that the date of images was unimportant.

Our results showed that shoot browning was distributed throughout the whole region of Extremadura, and probability maps revealed the existence of prevalent areas in both oak and cork oak forests. In holm oak, there were two main affected areas located in Llanos de Olivenza-Sierra Suroeste (SW sector) and La Siberia-Las Villuercas (E). In cork oak, there were three main affected areas located, in order of importance, in the Sierra de San Pedro (W sector), Sierra Suroeste (SW) and Los Ibores-Las Villuercas-La Siberia (E). A greater impact of shoot browning in cork than in holm oak was apparent both at the regional scale and at the stand scale. Alleged differences regarding vigour or defoliation between oak species did not explain the dissimilar incidence detected in shoot browning, a fact easily observable when observing images, particularly those from mixed stands. Instead, our results suggest a greater susceptibility of cork oak to C. florentinus and/or Diplodia, the two causal agents of shoot browning. The interaction we observed between oak species and stand type on damage is 
consistent with such a suggestion (see also Soria and Ocete 1993). A higher incidence in pure than in mixed stands of cork oak could be interpreted at first sight as an artefact derived from that in mixed stands there are fewer cork oaks available to be damaged, as mixed stands are occupied in part by holm oak trees. However, a concomitant, higher shoot browning incidence in mixed than in pure holm oak stands suggest that, in mixed stands, cork oak trees are putatively acting as a source of beetle pest/fungal inoculum for holm oak trees, which consequently suffer greater damage than expected. Our results on the clustered distribution of shoot browning damage at the stand scale are also consistent as they support the existence of stands with higher beetle populations and/or more fungal infestation foci.

Aspect and altitude, two geographical variables closely linked to temperature, also influenced shoot browning. Damage was prevalent in the sunniest orientations of the treetop and a related trend was observed when considering the stand aspect. A higher incidence of shoot browning in warmer parts of the treetop and sun-exposed oak stands is consistent with previous reports on the well-known heliophilic and thermophilic behaviour of C. florentinus (Cárdenas and Gallardo 2012, 2013; Soria and Ocete 1993), but also with the thermophilic nature of Diplodia species infecting oaks (Luque 1989). In the case of $C$. florentinus, thermophily explains why temperature rise derived from global warming has triggered the increase in damage reported in last years in France (Sallé et al. 2014) and Spain (Gallardo et al. 2018), and also why the beetle has expanded, since 1980, their septentrional distribution range towards northern France and southwestern Germany (Buse et al. 2013). Regarding the fungus, we found a similar scenario as oak-infesting Diplodia species exhibit an optimal growth at relatively high temperatures $\left(25-28^{\circ} \mathrm{C}\right.$ and even higher) (Luque 1989; Muñoz López et al. 1992) for which they are also scored as thermophilic or thermotolerant (Panzavolta et al. 2017). Beetle and fungus thermophily is also consistent with our results about the effect of the slope $\mathrm{x}$ aspect interaction on shoot browning in cork oak stands. In warm aspects, damage increases with ground slope, while in cold aspects, the opposite occurs. Such effect may be explained because in cold (north-facing) aspects, the higher the slope, the lesser the insolation on the treetops (especially in cold seasons), mainly due to the shadowing between contiguous trees. The opposite occurs in warm (south-facing) aspects in which the higher the ground slope, the higher the heat intake by treetops, as sun falls upon the ground more perpendicularly.

Altitude did not significantly affect shoot browning in cork oak trees, but there was a higher damage incidence in holm oaks living at higher altitudes $(>600 \mathrm{~m})$. In this regard, it is worth it to mention that, although $C$. florentinus and Diplodia widely affect both holm and cork oaks, our reiterated observations of shoot browning symptoms during this study (including size, colour, distribution and hanging aspect of damaged shoots) strongly suggest that cork oak could be more affected by the beetle, whereas holm oak could be more affected by the fungus. If our hypothesis is true, an increase in humidity with elevation could favour the development of Diplodia in holm oaks living at higher altitudes.

\section{Conclusions}

We provide the first integrating overview on the distribution and prevalence of oak shoot browning at a regional scale in SW Spain using a novel image-based prospecting method. We also define the effect of some underlying geographical/ ecological factors involved in oak shoot browning incidence. This information will be helpful in future researches for miscellaneous aspects such as to optimise resources and protocols in field surveys, to choose an appropriate field sampling method (e.g., probabilistic vs. stratified), to delimit risk/epidemic areas for forest management at early stages, to evaluate the spatiotemporal spread in next years under the current global warming scenario or to explore the true relationship between shoot browning and oak decay through geostatistical techniques. The relative importance of each causal agent involved (beetle vs. fungus) in shoot browning prevalence depending on oak species remains to be investigated.

Acknowledgments We greatly appreciate the constructive criticism of three anonymous reviewers. This research was supported by the Servicio de Sanidad Vegetal (SSV), Junta de Extremadura.

Data availability The raw datasets generated in the current study are available in the ResearchGate repository (Torres-Vila et al. 2019). Torres-Vila et al. (2019) Data from Mapping oak shoot browning in SW Spain using online imagery as virtual prospecting tool, Annals of Forest Science. V 06 March 2019. ResearchGate. [Dataset]. https://doi. org/10.13140/RG.2.2.24151.11687.

\section{Compliance with ethical standards}

Conflict of interests The authors declare that they have no conflict of interest.

\section{References}

Blondel J (2006) The 'design' of Mediterranean landscapes: a millennial story of humans and ecological systems during the historic period. Hum Ecol 34:713-729

Branco M, Bragança H, Sousa E, Phillips AJL (2014) Pests and diseases in Portuguese forestry: current and new threats. In: Reboredo F (ed) Forest context and policies in Portugal. Springer, Dordrecht, pp $117-154$

Brasier CM (1996) Phytophthora cinnamomi and oak decline in Southern Europe. Environmental constraints including climate change. Ann Sci For 53:347-358 
Brasier CM, Robredo F, Ferráz JFP (1993) Evidence for Phytophthora cinnamomi involvement in Iberian oak decline. Plant Pathol 42: $140-145$

Bugalho MN, Caldeira MC, Pereira JS, Aronson J, Pausas JG (2011) Mediterranean cork oak savannas require human use to sustain biodiversity and ecosystem services. Front Ecol Environ 9:278-286

Buse J, Griebeler EM, Niehuis M (2013) Rising temperatures explain past immigration of the thermophilic oak-inhabiting beetle Coraebus florentinus (Coleoptera: Buprestidae) in south-west Germany. Biodivers Conserv 22:1115-1131

Cárdenas AM, Gallardo P (2012) The effect of temperature on the preimaginal development of the Jewel beetle, Coraebus florentinus (Coleoptera: Buprestidae). Eur J Entomol 109:21-28

Cárdenas AM, Gallardo P (2013) The effects of oviposition site on the development of the wood borer Coraebus florentinus (Coleoptera: Buprestidae). Eur J Entomol 110:135-144

CEC [Council of the European Communities] (1992) Council Directive 92/43/EEC of 21 May 1992 on the conservation of natural habitats and of wild fauna and flora [habitats directive]. Off J Eur Communities 35:7-50

CNIG-IGN (2016) MDT05: Modelo Digital del Terreno con paso de malla 5m (SRG: ETRS89). Centro Nacional de Información Geográfica, Instituto Geográfico Nacional, Madrid. http:// centrodedescargas.cnig.es $/$ CentroDescargas/catalogo.do?Serie= LIDAR. Accessed 17 October 2018

Cowling RM, Rundel PW, Lamont BB, Arroyo MK, Arianoutsou M (1996) Plant diversity in Mediterranean-climate regions. Trends Ecol Evol 11:362-366

Desprez-Loustau ML, Marçais B, Nageleisen LM, Piou D, Vannini A (2006) Interactive effects of drought and pathogens in forest trees. Ann For Sci 63:597-612

Evans HF, Moraal LG, Pajares JA (2004) Biology, ecology and economic importance of Buprestidae and Cerambycidae. In: Lieutier F, Day KR, Battisti A, Grégoire J-C, Evans HF (eds) Bark and wood boring insects in living trees in Europe, a synthesis. Springer, Dordrecht, pp $447-474$

Frisullo S, Camele I, Carlucci A, Lops F (2000) Botryosphaeria and Botryosphaeria-like micromycetes on declining oaks in Apulia and Basilicata. Petria 10:1-10

Gallardo P, Cárdenas AM, Soriano JM (2018) Long-term assessment of selective pruning of Quercus species for controlling populations of Coraebus florentinus (Coleoptera: Buprestidae) in Mediterranean forests. Forests 9:49

Journel AG (1983) Nonparametric estimation of spatial distributions. J Int Assoc Math Geol 15:445-468

Jurc M, Bojović S, Komjanc B, Krć J (2009) Xylophagous entomofauna in branches of oaks (Quercus spp.) and its significance for oak health in the Karst region of Slovenia. Biologia 64:130-138

Linaldeddu BT, Scanu B, Maddau L, Franceschini A (2014) Diplodia corticola and Phytophthora cinnamomi: the main pathogens involved in holm oak decline on Caprera Island (Italy). Forest Pathol 44:191-200

Luque J (1989) Efectos de la temperatura, medio de cultivo y pH en el crecimiento colonial de Diplodia mutila Fr. apud Mont. An Jard Bot Madr 46:215-221

Manion PD (2003) Evolution of concepts in forest pathology. Phytopathology 93:1052-1055

Medail F, Quezel P (1999) Biodiversity hotspots in the Mediterranean Basin: setting global conservation priorities. Conserv Biol 13:1510 1513

Montero G, San Miguel A, Cañellas I (1998) Sistemas de silvicultura mediterránea La dehesa. In: Jiménez-Díaz RM, Lamo de Espinosa J (eds) Agricultura Sostenible. Agrofuturo, Life and Mundi-Prensa, Madrid, pp 519-554

Moreno G, Pulido FJ (2009) The functioning, management and persistence of dehesas. In: Rigueiro-Rodríguez A, McAdam J, Mosquera-
Losada MR (eds) Agroforestry in Europe. Springer, Dordrecht, pp $127-160$

Moricca S, Linaldeddu BT, Ginetti B, Scanu B, Franceschini A, Ragazzi A (2016) Endemic and emerging pathogens threatening cork oak trees: management options for conserving a unique forest ecosystem. Plant Dis 100:2184-2193

Muñoz López MC, Cobos Suárez P, Martínez Saavedra G (1992) La traqueomicosis de Diplodia sp. sobre Quercus sp. Bol San Veg Plagas 18:641-657

Myers N, Mittermeier RA, Mittermeier CG, Da Fonseca GAB, Kent J (2000) Biodiversity hotspots for conservation priorities. Nature 403: 853-858

Panzavolta T, Panichi A, Bracalini M, Croci F, Ginetti B, Ragazzi A, Tiberi R, Moricca S (2017) Dispersal and propagule pressure of Botryosphaeriaceae species in a declining oak stand is affected by insect vectors. Forests 8:228

Ramírez-Hernández A, Micó E, Marcos-García MA, Brustel H, Galante E (2014) The "dehesa", a key ecosystem in maintaining the diversity of Mediterranean saproxylic insects (Coleoptera and Diptera: Syrphidae). Biodivers Conserv 23:2069-2087

Rodríguez-Molina MC, Blanco-Santos A, Palo-Núñez EJ, Torres-Vila LM, Torres-Álvarez E, Suárez-de-la-Cámara MA (2005) Seasonal and spatial mortality patterns of holm oak seedlings in a reforested soil infected with Phytophthora cinnamomi. For Pathol 35:411-422

Rousselet J, Imbert C-E, Dekri A, Garcia J, Goussard F, Vincent B, Denux O, Robinet C, Dorkeld F, Roques A, Rossi J-P (2013) Assessing species distribution using Google Street View: a pilot study with the pine processionary moth. PLoS One 8:e74918

Sallé A, Nageleisen LM, Lieutier F (2014) Bark and wood boring insects involved in oak declines in Europe: current knowledge and future prospects in a context of climate change. For Ecol Manag 328:7993

Sánchez ME, Venegas JA, Romero MA, Phillips AJL (2003) Botryosphaeria and related taxa causing oak canker in southwestern Spain. Plant Dis 87:1515-1521

Scherrer B (1984) Biostatistique. Gaëtan Morin, Québec

Sokal RR, Rohlf FJ (1995) Biometry. Freeman and Co, New York

Solinas M (1971) Considerazioni ecologiche sul preoccupante sviluppo di Coroebus florentinus (Herbst) nelle leccete del Gargano. Entomologica 7:115-121

Solinas M (1974) Coroebus florentinus (Herbst) (Coleoptera Buprestidae) biologia, danni, lotta. Entomologica 10:141-193

Soria FJ, Ocete ME (1993) Estudios poblacionales sobre Coroebus florentinus (Herbst) (Col., Buprestidae) en alcornocales andaluces. Bol San Veg Plagas 19:27-35

Sturrock RN, Frankel SJ, Brown AV, Hennon PE, Kliejunas JT, Lewis KJ, Worrall JJ, Woods AJ (2011) Climate change and forest diseases. Plant Pathol 60:133-149

Thomas FM, Blank R, Hartmann G (2002) Abiotic and biotic factors and their interactions as causes of oak decline in Central Europe. For Pathol 32:277-307

Tiberi R, Branco M, Bracalini M, Croci F, Panzavolta T (2016) Cork oak pests: a review of insect damage and management. Ann For Sci 73: 219-232

Torres-Vila LM, Sánchez-González Á, Ponce-Escudero F, MartínVertedor D, Ferrero-García JJ (2012) Assessing mass trapping efficiency and population density of Cerambyx welensii Küster by mark-recapture in dehesa open woodlands. Eur J For Res 131: 1103-1116

Torres-Vila LM, Zugasti-Martínez C, Mendiola-Díaz FJ, De-JuanMurillo JM, Sánchez-González Á, Conejo-Rodríguez Y, PonceEscudero F, Fernández-Moreno F (2017) Larval assemblages of large saproxylic cerambycids in Iberian oak forests: wood quality and host preference shape resource partitioning. Popul Ecol 59:315328 
Torres-Vila LM, Echave-Sanabria AC, Mendiola-Díaz FJ, Moral-García FJ (2019) Data from mapping oak shoot browning in SW Spain using online imagery as virtual prospecting tool, Annals of Forest Science. V 06 March 2019. ResearchGate. [dataset]. https://doi.org/ 10.13140/RG.2.2.24151.11687

Vodka S, Konvicka M, Cizek L (2009) Habitat preferences of oak-feeding xylophagous beetles in a temperate woodland: implications for forest history and management. J Insect Conserv 13:553-562
Wargo PM (1996) Consequences of environmental stress on oak: predisposition to pathogens. Ann Sci For 53:359-368

Webster R, Oliver MA (2007) Geostatistics for environmental scientists. J. Wiley \& Sons Ltd., Chichester

Publisher's note Springer Nature remains neutral with regard to jurisdictional claims in published maps and institutional affiliations. 